\title{
David W. Fagerberg, Theologia prima. Czym jest teologia liturgiczna?, tłum. L. Bigaj, Fundacja Dominikański Ośrodek Liturgiczny, Kraków 2018 (Źródło i Szczyt, 5)
}

\author{
Bartłomiej K. Krzych \\ Uniwersytet Rzeszowski \\ bartlomiejkk@gmail.com http://orcid.org/0000-0003-2525-9759
}

Książka Theologia prima. Czym jest teologia liturgiczna? Davida W. Fagerberga została wydana w Polsce w 2018 roku nakładem Dominikańskiego Ośrodka Liturgicznego w ramach serii Źródło i Szczyt. Choć powstała jako rozprawa doktorska, okazuje się być zaskakująco przystępną książką o liturgii. Przedmiotem pracy Fagerberga jest - ściśle przez niego definiowana - teologia liturgiczna. Można powiedzieć, że autor dokonuje głębokiej i wszechstronnej analizy relacji prawa modlitwy (lex orandi) do prawa wiary (lex credendi). Książka Fagerberga jest jedną z najbardziej kompleksowych i innowacyjnych prac na ten temat.

Książkę charakteryzuje lekki styl, odpowiednio dobrane przykłady, klarowny wywód - to zapewne również zasługa autorki przekładu Laury Bigaj. Mimo że pewne szczegółowe stwierdzenia lub uwagi mogą budzić wątpliwości zarówno z punktu widzenia czysto liturgicznego, w tym ortopraksji (mimo że autor nie podaje żadnych postulatów ściśle praktycznych, ograniczając się do podkreślania prawdziwie ekumenicznej wartości swoich refleksji), jak i ortodoksji teologicznej (autor jest konwertytą z luteranizmu i często odwołuje się do myśli reformackiej, ale też wschodniej).

Theologia prima składa się z przedmowy autora do wydania polskiego, słowa wstępnego, ośmiu rozdziałów podzielonych na trzy części, aneksu i indeksu. W pierwszej części Fagerberg odpowiada na pytanie o to, czym jest teologia liturgiczna, wskazując również jej miejsce w taksonomii dyscyplin teologicznych, a także na pionierską w tym względzie postać jego mistrza Aleksandra Schmemanna. Kilkukrotnie podkreśla on, że przyznaje liturgii miejsce uprzywilejowane, niejako źródłowe dla całej teologii, co odwraca powszechne patrzenie na tę sprawę (w pierwszych klasyfikacjach tzw. miejsc teologicznych nie pojawiała się liturgia). Na pytanie o wygląd teologii liturgicznej 
oraz jej praktyczny wymiar znajdujemy odpowiedź w części drugiej, gdzie pojawia się postać pani Murphy, powołana do życia przez Kavanagha, drugiego mistrza Fagerberga (trzeba zauważyć, że pani Murphy łudząco przypomina wetulę, czyli staruszkę św. Tomasza z Akwinu, jednakże słusznie można sądzić, że dominikanin nie przypisałby jej tak wielkich umiejętności i zdolności teologicznych czy też teologiczno-twórczych, jak amerykański liturgista). Słowem: autor wyjaśnia, jak to się dzieje, że sprawujący i uczestniczący w liturgii dokonują rzeczywiście i prawdziwie aktu teologicznego, będąc tym samym przedstawicielami teologii pierwszej, teologii w ruchu - jak ją określa Fagerberg, w odróżnieniu od teologów drugiego poziomu, czyli akademików. Amerykanin zaznacza jednak, że nie można zarysować ostrej linii podziału, wręcz przeciwnie, pokazuje, jak można, a nawet powinno się łączyć teologię pierwszą z teologią drugą - w zasadzie nie można oddzielić jednej od drugiej bez straty dla obu stron, można powiedzieć, że w ich relacji kluczowe jest wzajemne pobudzanie i weryfikowanie się. Trzecia część to omówienie dwóch przykładów teologii liturgicznej - starożytnego i współczesnego. Pierwszy przykład to komentarz mistagogiczny św. Germana z Konstantynopola, drugi zaś to dzieło Eucharystia Aleksandra Schmemanna. Tę część zamyka dodany w kilka lat po obronie doktoratu (podobnie jak pierwszy) rozdział zatytułowany Centuria konsekwencji. Jest to zbiór krótkich i syntetycznych wskazówek, wniosków, przykładów lub cytatów stanowiących esencję teologii liturgicznej Fagerberga. W polskim wydaniu znalazł się również aneks z zapisem konferencji autora wygłoszonej w Lublinie w 2010 roku, w której opowiada o tym, dlaczego został katolikiem - jak sam twierdzi, jego nawrócenie dokonało się podczas pisania piątego rozdziału rozprawy doktorskiej (autor wspomina o tym również w słowach wprowadzających w lekturę). Tekst wykładu poprzedza krótkie, ale wartościowe wprowadzenie od redakcji (ks. Krzysztof Porosło), w którym nakreślono nie tylko kontekst złożonego przez Fagerberga w Polsce „świadectwa”, ale również objaśniono status i miejsce dzieła amerykańskiego liturgisty na mapie refleksji teologicznej. Ks. Porosło zestawia ze sobą amerykańską szkołę Schmemann, Kavanagh, Fagerberg i rzymską szkołę Vagaggini, Marsili, Triacca, wskazując zarówno na brak badań porównawczych w tym względzie, jak też luki w polskim piśmiennictwie.

Już w przedmowie do polskiego wydania, odwołując się do Schmemanna i Kavanagha, Fagerberg stwierdza, że „liturgia jest teologią” (s. 12), a nie tylko jednym z miejsc lub źródeł teologicznych i tak w dotychczasowej praktyce traktowanym po macoszemu, najczęściej wybiórczo i in abstracto, tj. w oderwaniu 
od całości sprawowanego rytu. Dla autora omawianej pozycji „,w sformułowaniu teologia liturgiczna słowa są ze sobą zintegrowane i odnoszą się do jednej rzeczywistości (tak jak słowa ciało i dusza odnoszą się do jednej rzeczywistości osoby)” (s. 14). Już w tym miejscu można dostrzec, jak istotny jest dla amerykańskiego liturgisty teologiczny potencjał zawarty w liturgii, potencjał, który w momencie jej sprawowania staje się aktem teologicznym. W przedmowie pojawiają się jeszcze dwa fragmenty, które stanowią syntezę całej pracy:

Pierwotne miejsce występowania teologii liturgicznej to Kościół (theologia prima) - uczelnia zajmuje dopiero drugie miejsce (theologia secunda). Właśnie dlatego Schmemann nazywa liturgię locus theologicus par excellence i dlatego Kavanagh określa liturgię wiarą Kościoła objawianą i przechowywaną w rycie jako lex orandi (s. 14-15).

Twierdzę jednak, że liturgia to teologia pierwsza, a tym, co zajmuje najwyższą i najważniejszą (prymarną) pozycję, jest teologia realizowana w liturgii. Szkoła, z którą się identyfikuję, przypisuje taką wartość lex orandi Kościoła (s. 17).

Kolejne rozdziały książki służą eksplikacji i szerokiemu uargumentowaniu sformułowanych tez. Nie można pominąć zastrzeżeń, jakie jasno wyraża autor: „nie uważam, że liturgia rozmywa teologię: uważam, że teologia liturgiczna rozszerza nasz sposób pojmowania zarówno liturgii, jak i teologii” (s. 23). Natomiast połączenie czy też zjednoczenie liturgii i teologii dokonuje się za sprawą ascetyzmu, który jest dziełem i warunkiem chrześcijańskiej liturgii (zob. s. 25). Odwołując się (i to wielokrotnie) do Ludwiga Wittgensteina i jego teorii gier językowych, Fagerberg określa teologię liturgiczną jako „gramatykę wiary w praktyce” odkrywaną w strukturze liturgii (ryt i jego części traktowane jako całość) i kształtującą życie liturgów (wszystkich uczestników liturgii, przedstawicieli teologii pierwszej; por. s. 32-33). Innymi słowy „teologia liturgiczna to teologia, która jest liturgicznie wcielona” (s. 37), zaś „wszystko, czym posługujemy się w chrześcijańskiej liturgii, przeszło przez unię hipostatyczną” (s. 50). Teologię liturgiczną określa również jako „eklezjologiczną autoanalizę” (s. 56).

Wykorzystanie teorii Wittgensteina może budzić pewne zastrzeżenia, bowiem filozofia języka znacząco się rozwinęła, pojawiło się wielu krytyków jego poglądów lub też myślicieli tworzących odmienne, czasami wręcz sprzeczne z myślą austriackiego filozofa teorie (od egzystencjalizmu przez różne prądy filozofii analitycznej po hermeneutykę i postmodernistów). Fagerberg traktuje liturgię jako rzeczywistość realną, natomiast Wittgenstein jest uważany 
za nominalistę. Owszem, możemy uznać bez narażania się na oburzenie znawców jego myśli, że dla autora Dociekań filozoficznych język pełni funkcję performatywną (słowa, które wywołują, sprawiają działanie), ale ze względu na ontologiczny nominalizm takie podejście wspierałoby teorię symbolu krytykowaną przez Fagerberga. Niemniej trudno liturgiście zarzucać brak pogłębionego rozumienia założeń filozoficznych oraz ich konsekwencji. Autor korzysta z nich pomocniczo, prawdopodobnie nie będąc świadomym ukrytych w myśli Wittgensteina przesłanek. Wszelako nie jest to powód, by dyskredytować jego dzieło oraz intelektualny wysiłek włożony w odkrywanie i odkopywanie zapomnianych spojrzeń na liturgię - żywych w pierwszych wiekach chrześcijaństwa i epoce ojców Kościoła.

U Fagerberga znajdujemy również stwierdzenia przynajmniej na pierwszy rzut oka zaskakujące, bo kłócące się z powszechnymi mniemaniami czy „frazesami” teologicznymi, np. „liturgia nie jest religią chrześcijan”, ponieważ „liturgia to religia Chrystusa utrwalana w chrześcijanach” (s. 52). Nieco dalej: „Liturgia to nie wyraz naszej religijności, ale teologia samego Boga” (s. 53). Co więcej, „liturgia to nie tylko rytuał; to wyrażony rytualnie sposób życia i sposób myślenia” (s. 65) - stąd tak istotną rolę Fagerberg przypisuje ascezie (którą również pojmuje we właściwy sobie sposób, por. s. 60-81). Jeszcze jedno istotne zdanie: „Teologia, która jest liturgiczna, rodzi się w strukturach liturgicznych i nigdy się od nich nie odrywa; liturgia to teologia w działaniu, a nie jedynie źródło rubryk do grzebania dla rzekomo prawdziwych teologów" (s. 91). Istotne więc okazują się nie tylko rubryki, ale nade wszystko nigryki, ale w połączeniu z rubrykami i znaczeniem, żywą symboliką sprawowanych czynności - żywą, czyli tworzącą rzeczywistość, niebędącą tylko odbiciem innego świata, jak twierdzi Fagerberg.

Na dalszych stronach autor omawia główne cechy teologii kultu i teologii z kultu, by następnie zestawić je z teologią liturgiczną, o której mówi i wskazać na zachodzące między nimi różnice (s. 83-131). Zwracam uwagę na trzy istotne uwagi, jakie znajdujemy w tym miejscu u Fagerberga: (1) „Liturgia musi być poddawana teologicznej krytyce - inaczej będziemy tkwić w dychotomii, kojarząc liturgię z estetyką (a nie z teologią), a teologię z doktryną (a nie z liturgią) (s. 127); (2) „realizacja rytu liturgicznego powołuje rzeczywistość do życia, a nie jest zaledwie jej wyrazem” (s. 128) - Fagerberg mocno krytykuje upadek teorii symbolu i alegorii, opowiadając się przeciwko redukcjonizmowi, który symbol identyfikuje jako pewne odwzorowanie, naśladowanie innej rzeczywistości; dla niego sam symbol, a zatem sama liturgia stanowi pewną rzeczywistość); 
(3) „warunkiem do realizowania teologii akademickiej jest wykształcenie; warunkiem do realizowania teologii liturgicznej jest świętość” (s. 129).

Kolejne rozdziały, mimo że są w większej mierze poświęcone myśli mistrzów Fagerberga, zwłaszcza Aleksandrowi Schmemannowi, przynoszą kolejne celne i wartościowe stwierdzenia. Autor słusznie zauważa, że „zarówno liturgia, jak i teologia ulegają zniekształceniu, gdy podawane są w oderwaniu od siebie” (s. 141). Dla amerykańskiego liturgisty esencją liturgii, a więc prawa modlitwy (lex orandi), jest „sama wiara Kościoła” (s. 144, por. s. 177-178), dlatego też za uprawnione można uznać kolejne słowa, w których mówi o liturgii jako ontologicznym warunku teologii - „liturgia to osiągnięcie zbawienia, o którym mówi teologia” (s. 157). Ostrożność jednak wymaga, aby mieć się na baczności i czuwać nad wiarą, która jest celebrowana, ponieważ nie może to być wiara byle jaka, ale właśnie wiara Kościoła, a ta jest nierozerwalnie związana z Bożym Objawieniem i ewangelicznym przesłaniem Jezusa Chrystusa przekazanym nam przez apostołów.

W rozdziale czwartym Fagerberg, wychodząc od definicji liturgii jako aktu teologii (zob. s. 183), dokonuje porównania liturgii z leitourgia. Mówiąc w skrócie: ta pierwsza odpowiada na pytanie „jak”, zaś ta druga na pytanie „co”. „Leitourgia zajmuje się tym, co nadaje rubrykom sens i wartość” (s. 185).

Kolejny rozdział poświęcony jest pani Murphy, w którym Fagerberg wykazuje, że każdy z nas jest lub też może być prawdziwym liturgiem (liturg dla Amerykanina nie jest równoznaczny z liturgistą, czyli znawcą historii liturgii i rubryk) i teologiem (teologia pierwsza), a rozdziały 6 i 7 - analizie dwóch dzieł będących zapisem myślenia osadzonego w Fagerbergowskiej teologii liturgicznej.

Warto zwrócić uwagę na kilka centuriów konsekwencji (rozdział 8), przy czym autor postuluje, aby je czytać całościowo jako „uzupełniające się bieguny antynomii” (s. 342). Na samym początku czytamy, że „1. Liturgia to wiara Kościoła w ruchu” (s. 342). Co to oznacza? Aby wyjaśnić to stwierdzenie, Fagerberg używa obrazowych przykładów i metafor (których odkrycie również pozostawiam czytelnikom). Jeśli natomiast chodzi o samą teologię liturgiczną, to „8. [...] staje się dla nas niedostępna, jeśli traktujemy liturgię jako wyraz naszych uczuć, a nie źródło naszej chrześcijańskiej tożsamości” (s. 345). Dowiadujemy się też, że „64. [...] Liturgia jednak jest mikrokosmosem czasu, a także przestrzeni” (s. 361) - słowa te zapewne nie zaskoczą teologów i ludzi wiary, myślę jednak, że mogą stanowić inspirację dla badań z pogranicza teologii i nauki, w których często pomijana jest liturgia, a przecież pytania 
o teologiczną naturę czasu i przestrzeni, jak też ontologiczny i epistemologiczny wymiar liturgii (szczególnie np. kwestia realnej obecności Chrystusa pod postaciami chleba i wina) - właśnie w kontekście wiedzy naukowej - są po pierwsze zasadne, po drugie - interesujące. Nierzadko możemy spotkać się z przewrażliwionymi rubrycystami, którzy przeczytali jeden lub dwa podręczniki do ceremonii. Co ma im do powiedzenia Fagerberg? „72. Niech anioły zajmą się idealną liturgią; jeśli chodzi o liturgię anthropos - wystarczy, że będzie sensowna” (s. 363).

Z tą ostatnią myślą związany jest też tzw. błąd narzędziowy w podejściu do liturgii, jej rozumieniu i przeżywaniu. Warto zwrócić na tę kwestię szczególną uwagę nawet kosztem innych, jak np. antynomii ukrytych w liturgii czy szerszego omówienia teorii ascetyzmu liturgicznego Fagerberga. Fagerberg wprowadza do problemu następująco: „Mówiąc, że akt liturgiczny jest aktem teologicznym, a nie zaledwie przedmiotem lub źródłem aktu teologicznego, musimy zacząć pojmować leitourgia w innym kluczu niż ten, do którego jesteśmy przyzwyczajeni. Aby zobaczyć liturgię jako theologia prima wspólnoty, musimy zacząć pojmować ją jako coś więcej niż nastrój, styl czy sposób wyrazu; musimy zacząć traktować liturgię jako ryt, a nie zaledwie protokół” (s. 186). Odwołuje się on do myśli Kavanagha: „ "Liturgia zaczęła się stawać obrzędem» (A. Kavanagh, On Liturgical Theology, s. 109)” (s. 187). Dalej Fagerberg przechodzi do sedna:

Dlaczego przejście od leitourgia do liturgii pozostało niemal niezauważone? Ze względu na redukcjonizm, o którym pisał Schmemann? A może na skutek zaniku rytu, jak sugeruje Kavanagh? Myślę, że z obydwu tych przyczyn. Najbardziej dotkliwym skutkiem tak osłabionego poczucia leitourgia jest widoczna utrata wrażliwości na tożsamość eklezjalną i na głęboką strukturę samej liturgii. Kult zaczyna być postrzegany jako środek do osiągnięcia celu, a nie jako cel sam w sobie, liturgia natomiast zaczyna być pojmowana jako jeden z wielu środków budowania, nawoływania, stymulowania czy nauczania chrześcijan o Bogu, a nie jako spotkanie odbijające się echem w życiu wiernych (ascetyzm) oraz w ich wiedzy (teologia). R. Taylor Scott nadał temu nieporozumieniu ciekawą nazwę. „Uważam, że największym współczesnym problemem dotyczącym rozumienia liturgii jest błąd narzędziowy. Błąd ten polega na tym, że wszelkie słowa, ubiory, pieśni, kazania, ruchy, itp., które razem wzięte stanowią liturgię, istnieją tylko po to, by duchowo zaspokajać i ubogacać poszczególnych uczestników. Krótko mówiąc, liturgia staje się narzędziem służącym osobistemu rozwojowi jednostki. Nie ma absolutnie nic problematycznego w indywidualnej pobożności, ale nie stanowi to liturgii [...]" (R. Taylor Scott, The Likelihood of Liturgy: Reflection Upon Prayer Book Revision and Its Liturgical Implications, „Anglican Theological Review” 1980, 
57 (2), s. 106). Parafrazując to za pomocą naszej terminologii, nie ma nic problematycznego w indywidualnej pobożności realizowanej w towarzystwie innych (liturgia w rozumieniu wąskim), ale nie to stanowi leitourgia" (s. 187-188).

Każdy - zwłaszcza kapłani i osoby szczególnie zaangażowane w liturgię (ministranci, kantorzy, zakrystianie, śpiewacy, etc.) - powinien przynajmniej co jakiś czas dokonać „liturgicznego” rachunku sumienia. Biorąc pod uwagę znaczenie Fagerbergowskie znaczenie terminu „liturgiczny”, owa examinatio będzie dotyczyć w równym stopniu naszego życia i postępowania, bowiem lex orandi - lex credendi - lex vivendi (a nawet - lex moriendi), w myśl triadycznej koncepcji rzymskiej szkoły teologii liturgicznej mysterium - actio - vita.

Lektura książki Fagerberga może wzbudzić pewne wątpliwości. Pierwsza dotyczy powszechności liturgów-teologów, czyli tych, którzy biorą czynny udział w liturgii (participatio actuosa). Na jakich warunkach dokonuje się uznanie tego, czego dokonują w domenie teologii? Czy ascetyzm jest warunkiem wystarczającym i koniecznym? Druga wątpliwość jest związana z pierwszą. Fagerberg, mimo że nie chce tworzyć wyraźnego podziału, zdaje się deprecjonować pracę liturgistów-uczonych, zwłaszcza z obszaru historii. Traktuje ją bowiem jako pewien dodatek do „pracy” liturgów sprawujących święte misteria. Jak traktować liturgów-liturgistów? Czy jako uczeni są liturgami na tych samych warunkach co pani Murphy? Zabrakło w omawianej pracy naprawdę precyzyjnego omówienia tych kwestii i relacji. Znak zapytania pojawia się również przy przekonaniu Fagerberga o nieprzeciętnie ekumenicznym charakterze teologii liturgicznej. Ma ona być jego zdaniem miejscem swoistego zaniechania nieistotnych różnic liturgicznych i teologicznych, które pojawiły się w momencie porzucenia pierwotnego ideału liturgii. Celem zaś teologii liturgicznej jest rytualna komunia chrześcijan. Autor jednakże nie formułuje żadnych praktycznych i teoretycznych wskazań. Jego nadzieje mogą być mało zasadne, ponieważ wydaje się zakładać, iż będzie w stanie „zadowolić” wszystkich.

Powyżej naszkicowano najważniejsze koncepcje zawarte w książce Fagerberga. Ten zarys pozwala zorientować się w jakości i znaczeniu tego dzieła, zwłaszcza w odnowie czy też ponownym, stale dokonywanym pogłębianiu liturgicznej świadomości. Podsumowując, Theologia prima to ważna publikacja na rodzimym rynku wydawniczym, która przybliża polskiemu czytelnikowi najważniejsze zagadnienia dotyczące naszego rytualnego sposobu życia i myślenia. 